\title{
Lung cancer in never-smokers: radon exposure and environmental tobacco smoke
}

\author{
Boris B.M. Melloni
}

Affiliation: University of Limoges, Respiratory Dept, CHU Limoges, Limoges, France.

Correspondence: Boris B.M. Melloni, Respiratory Dept, CHU Limoges, 87042 Limoges, France. E-mail: boris.mellonidunilim.fr

0

@ERSpublications

Indoor radon exposure and ETS should be considered as factors in never-smoker lung cancer patients http://ow.ly/zPpDG

Lung cancer occurs in subjects with no history of active smoking in $15-25 \%$ of all cases, mainly females. Lung cancer in never-smokers is a recent field of investigation, with differences in clinical, pathological and molecular aspects compared with lung cancer in smokers [1,2]. Chronic exposure to radon and its decay products is recognised as the second leading cause of lung cancer, after active cigarette smoking. Alpha particle emissions from inhaled radon decay products, and not radon itself, cause lung cancer [3]. Alpha particles, which can only penetrate a short distance into bronchial epithelium, induce more biological damage than beta or gamma radiation, and can induce DNA base mutations and chromosomal strand breaks.

The first description of environmental causes of lung cancer dates back to 1879 and was made in the mining town of Schneeberg in the German state of Saxony [4]. Many epidemiological studies of miners reported a strong association between radon exposure and lung cancer risk $[1,3]$. Never-smokers represented a significant share of these workers. In 1988, the International Agency for Research on Cancer recognised radon as a group 1 carcinogen, based on the results of epidemiological studies in uranium miners [5]. More recently, the risk for the general population of exposure to indoor radon has been outlined [1]. A metaanalysis of 13 European studies shows that the relative risk of lung cancer is increased among nonsmokers and smokers with a radon exposure of $>200 \mathrm{~Bq} \cdot \mathrm{m}^{-3}$. In addition, this relative risk is increased further in cigarette smokers and recent ex-smokers who are also exposed to indoor radon [6].

Environmental tobacco smoke (ETS) is considered a possible cause of lung cancer in never-smokers, as confirmed by many studies. A meta-analysis of 55 studies of never-smoking wives, living with smokers, showed a significant increase of lung cancer [7]. ETS is recognised as a possible cause of lung cancer in never-smokers, but concomitant exposure to occupational agents or indoor radon should be considered [1].

Epidemiological studies have demonstrated the synergistic effect between radon and tobacco smoke [6]. It has been shown that, for the same exposure to radon and decay products, the risk of lung cancer is greater in smokers compared with nonsmokers [3].

In this issue of the European Respiratory Journal, TORRES-DuRÁN et al. [8] report a case-control study on lung cancer in never-smokers with or without exposure to residential radon in Galicia, Spain. Few studies have analysed the role of combined radon and ETS exposures in lung cancer risk in nonsmokers. Following a published meta-analysis, the authors demonstrated that a radon exposure of $>200 \mathrm{~Bq} \cdot \mathrm{m}^{-3}$ significantly increases lung cancer risk in never-smokers (odds ratio of 2.42), compared with individuals exposed to $<100 \mathrm{~Bq} \cdot \mathrm{m}^{-3}[8,9]$. Within this population, the odds ratio increases to 2.84 for females exposed to

Received: July 012014 | Accepted after revision: July 112014

Conflict of interest: None declared.

Copyright @ERS 2014 
$>200 \mathrm{~Bq} \cdot \mathrm{m}^{-3}$. The main point of this article is the confirmation of two previous studies in never-smokers: a European pooling study and a Swedish epidemiological study $[6,10]$. Once more, in this study in Galicia, the ETS exposure at home is proved to be a significant factor for increased lung cancer risk in a population exposed to $>200 \mathrm{~Bq} \cdot \mathrm{m}^{-3}$. ETS is difficult to evaluate in epidemiological studies and this point is outlined in the discussion of this article by TORRES-Durán et al. [8]. The authors have chosen three conditions: $0,1-35$ or $\geqslant 36$ years living with a smoker. Individuals exposed to radon $>200 \mathrm{~Bq} \cdot \mathrm{m}^{-3}$ have an odds ratio of 1.99 without ETS exposure and this rises to 2.75 if they have lived 1-35 years with a smoker. The two determinant items of this case-control epidemiological study are the high rate of radon detector return and the high numbers of years that the population lived in the same house, in this area of Galicia, Spain. However, cases of nonsmoker males represented only 20\%, and adenocarcinoma was the main histological type $(77.5 \%)$, as in never-smokers with lung cancer $[1,2]$.

The majority of acquired molecular abnormalities have been described in lung cancer patients with a neversmoking history. It would have been interesting to know the percentage of these mutations in the lung cancer pathological specimens from patients exposed to radon alone compared with radon plus ETS. Interestingly, the same team have studied, in blood samples of the Galicia case-study population, the expression of two members of the glutathione S-transferase family, enzymes that are involved in detoxification [11]. The risk of lung cancer is significantly higher in patients with GSTM1 or GSTT1 gene deletions who are exposed to radon, independent of the level of radon exposure.

Another informative detail of this article is the choice of the cut-off points for radon exposure of 100, 148 and $200 \mathrm{~Bq} \cdot \mathrm{m}^{-3}$. The World Health Organization recently decided to lower the recommended level to $<100 \mathrm{~Bq} \cdot \mathrm{m}^{-3}$, whereas the US Environmental Protection Agency established, in $1987,148 \mathrm{~Bq} \cdot \mathrm{m}^{-3}$ as the action level to minimise health hazards due to indoor radon exposure $[5,12]$. In the case-control study in Galicia, Spain, the risk of lung cancer is significant at $>200 \mathrm{~Bq} \cdot \mathrm{m}^{-3}$ for never-smokers, as reported in the literature. Conversely, an exposure to $<100 \mathrm{~Bq} \cdot \mathrm{m}^{-3}$ does not seem to induce a risk of lung cancer in neversmokers exposed to radon alone or radon plus ETS. Previously, the scientific community has estimated the risk at low doses on the basis of a linear, no-threshold, dose-response relationship, with the potential risk at low doses extrapolated from medium or higher doses of radon exposures.

Recently, a prospective study has focused on mortality from non-malignant respiratory diseases and residential radon exposure. This large study, Cancer Prevention Study II, has demonstrated that mortality from chronic obstructive pulmonary disease increases with exposure to increased radon concentrations [13]. This analysis must be cautious because residential radon exposure is based on ecological indicators and not on analysis from radon detectors at home. No information on smoking habits or ETS is known for the studied population. For Chinese males, intense incense exposure and cigarette smoking have a synergistic effect on lung cancer [14]. Preliminary data from this study suggest that radon exposure increases the risk of lung cancer in smokers exposed to incense.

In conclusion, indoor radon exposure should be considered as a factor in never-smoker lung cancer patients. Buildings or houses with high radon concentration must be identified. New constructions should be "radon-proof". The combination of radon remediation and ETS exposure cessation should be discussed and proposed by public health authorities, as outlined by the results of the case study of TORRES-Durán et al. [8]. This case-control study gives us new information about the essential role of indoor radon and/or ETS exposure in the risk of lung cancer in never-smokers.

\section{References}

1 Samet JM, Avila-Tang E, Boffetta P, et al. Lung cancer in never smokers: clinical epidemiology and environmental risk factors. Clin Cancer Res 2009; 15: 5626-5645.

2 McCarthy WJ, Meza R, Jeon J, et al. Chapter 6. Lung cancer in never smokers: epidemiology and risk prediction models. Risk Anal 2012; 32: Suppl. 1, S69-S84.

3 Tirmarche M, Harrison JD, Laurier D, et al. ICPR Publication 115. Lung cancer risk from radon and progeny and statement on radon. Ann ICPR 2010; 40: 1-64.

4 Harting FH, Hesse W. Der Lungenkrebs, die Bergkrankheit in den Schneeberger Gruben [Lung cancer, the mountain sickness in the Schneeberger pits]. Viertelj Gerichtl Med Off Sanitäts 1879; 31: 102-132.

Man-made Mineral Fibres and Radon. IARC Monogr Eval Carcinog Risk Hum 1988; 43: 1-300.

6 Darby S, Hill D, Auvinen A, et al. Radon in homes and risk of lung cancer: collaborative analysis of individual data from 13 European case-control studies. BMJ 2005; 330: 223.

7 Taylor R, Najafi F, Dobson A. Meta-analysis of studies of passive smoking and lung cancer: effects of study type and continent. Int J Epidemiol 2007; 36: 1048-1059.

8 Torres-Durán M, Ruano-Ravina A, Parente-Lamelas I, et al. Lung cancer in never-smokers: a case-control study in a radon-prone area (Galicia, Spain). Eur Respir J 2014; 44: 994-1001.

9 Torres-Durán M, Barros-Dios JM, Fernándes-Villar A, et al. Residential radon and lung cancer in never smokers. A systematic review. Cancer Lett 2014; 345: 21-26.

10 Lagarde F, Axelsson G, Damber L, et al. Residential radon and lung cancer among never-smokers in Sweden. Epidemiology 2001; 12: 396-404. 
11 Ruano-Ravina A, Pereyra MF, Castro MT, et al. Genetic susceptibility, residential radon, and lung cancer in a radon prone area. J Thorac Oncol 2014 [In press DOI: 10.1097/JTO.0000000000000205].

12 Handbook on Indoor Radon. A Public Health Perspective. Geneva, World Health Organization, 2009.

13 Turner MC, Krewski D, Chen Y, et al. Radon and COPD mortality in the American Cancer Society Cohort. Eur Respir J 2012; 39: 1113-1119.

14 Tse LA, Yu IT, Qiu H, et al. A case-referent study of lung cancer and incense smoke, smoking, and residential radon in Chinese men. Environ Health Perspect 2011; 119: 1641-1646. 